\title{
Evaluation of protein level's changes in saliva and sera of Oral Squamous Cell Carcinoma patients
}

\author{
Hathama R. Hasan* \\ Received 20, December, 2012 \\ Accepted 5, February, 2014
}

Nuha N. Abdelwahb*

\begin{abstract}
:
This study aimed to identify the changes in total protein in saliva and sera samples of patients with oral squamous cell carcinoma in comparison to those of healthy controls. These changes were followed using electrophoresis (PAGE). Meanwhile, determinations of albumin, globulin and albumin to globulin ratio were carried out on sera samples only.

Two groups were the participants in the present study, 18 patients with Oral Squamous Cell Carcinoma (OSCC), and 20 ages and gender matched healthy controls.
\end{abstract}

Key words: Oral cancer, Squamous cell carcinomas, Saliva, Albumin.

\section{Introduction:}

Oral cancer is one of the most common cancers in the world, with approximately 274300 new cases and 127500 deaths occurring each year [1]. Over $90 \%$ of oral cancers are Squamous Cell Carcinomas [2, 3]. In Iraq, according to Iraqi national cancer registry, oral cancers accounts for about $1.8-2 \%$ of all malignancies during the years 2000-2004 with an incidences of $0.77,1.2,0.88$ and 1.14 per 100000 population for the years 2000, 2001, 2003 and 2004 respectively (Results of Iraqi cancer registry, 2000, 2001, 2003, 2004)[4]. (Kurdistan provinces are not included in this registry).

Proteins are major components of all cells, and present in all body fluids [5]. Over 100 individual proteins have a physiological function in serum. The proteins of the plasma are actually a complex mixture that includes not only simple proteins but also conjugated proteins such as glycoproteins and various types of lipoproteins [6, 7]. Quantitatively, the single most important protein in the human body is albumin $(3.5$ to $5 \mathrm{~g} / \mathrm{dl})$, the other proteins are known collectively as globulins $(2.5-3.5 \mathrm{~g} / \mathrm{dl})$ $[8,9]$. So any Changes in the concentration of these individual proteins will lead to a change in total serum protein.

Saliva is a complex fluid produced by a number of specialized glands and secreted into the oral cavity of mammalian vertebrates. Most of the saliva is produced by the major salivary glands (parotid, submandibular and sublingual) but a small contribution is made by the numerous small labial, buccal and palatal glands which line the mouth [10]. Salivary proteins may be originated as an ultra-filtrate of plasma proteins or through salivary \& mucosal secretions, so any violation to the integrity of capillary bed or mucosal lining as occurs in oral neoplasia may be associated with an increase in salivary proteins especially albumin.

*Department of chemistry, college of Science, Baghdad University 


\section{Materials and methods:}

This study was carried out during the period of about a year and a half at the chemistry department college of science Baghdad University. The patients group was those who attended department of Oral and Maxillofacial Surgery (Al Wasity Hospital and Hospital of Specialized Surgeries of the Medical City in Baghdad).

Patients with Oral Squamous Cell Carcinoma $(n=18)$ were included in the current study, as well as $(n=20)$ controls matched for age and gender (Table1).

Provisional diagnosis was made by the clinical specialists. The final diagnosis was confirmed by Histopathological examination. The healthy individuals were nonsmoking and nondrinking volunteers who were not suffering from any disease and matched for age and gender were also included to be used as control.

Table 1: Distribution by age, sex, and histological classification for the study (Oral Squamous Cell Carcinoma \& controls).

\begin{tabular}{|c|c|c|c|c|c|}
\hline Group & $\begin{array}{c}\mathbf{N} \\
\mathbf{0 .}\end{array}$ & $\begin{array}{c}\text { Gend } \\
\text { er }\end{array}$ & $\begin{array}{c}\text { Age } \\
\text { (years) } \\
\text { Mean } \pm \text { S } \\
\mathbf{D} \\
\text { (Range) }\end{array}$ & $\begin{array}{c}\text { Samples } \\
\text { used }\end{array}$ & $\begin{array}{c}\text { Type of } \\
\text { tumors }\end{array}$ \\
\hline Control & 20 & $\begin{array}{c}11 \\
\text { males } \\
\text { femal } \\
\text { es }\end{array}$ & $\begin{array}{c}56.45 \pm 10 . \\
17 \\
(46-79)\end{array}$ & $\begin{array}{c}\text { Blood\&sal } \\
\text { iva }\end{array}$ & - \\
\hline $\begin{array}{c}\text { Maligna } \\
\text { nt }\end{array}$ & 18 & $\begin{array}{c}10 \\
\text { males } \\
\text { (OSCC) }\end{array}$ & $\begin{array}{c}59.24 \pm 11 . \\
63\end{array}$ & $\begin{array}{c}\text { Blood\&sal } \\
\text { iva }\end{array}$ & $\begin{array}{c}\text { Squamo } \\
\text { us cell } \\
\text { carcino } \\
\text { ma }\end{array}$ \\
\hline
\end{tabular}

Saliva and blood samples were collected from each individual:

Unstimulated 5 to $10 \mathrm{~mL}$ whole, mixed-saliva samples, were collected and preserved in an ice container under resting conditions in a quiet room between 8.0-9.0 A.M. Patients and healthy individuals were asked to rinse their mouth with normal saline, then to generate saliva in their mouth and to spit into a plastic container for 10 minutes. The saliva sample was immediately divided into two test tubes, the first one (total saliva) was stored frozen, while the remaining saliva in the second tube was centrifuged at $(2000 \mathrm{xg})$ for 10 minutes at $4{ }^{\circ} \mathrm{C}$ to obtain the supernatant. The resulting supernatant and Pellet were stored frozen at $-20{ }^{\circ} \mathrm{C}$ in polyethylene tubes until they were used for the assay.

Ten milliliters of venous blood samples were collected by using plastic disposable syringes from overnight fasting patients (before surgery), and from the control groups, in plane polyethylene tube. Samples were allowed to clot for ten minutes at $37{ }^{\circ} \mathrm{C}$ in water bath, and then blood samples were centrifuged at $(3000 \mathrm{x} \mathrm{g})$ for 10 minutes. The obtained clear serum supernatant was stored frozen at $-20{ }^{\circ} \mathrm{C}$ until it was assayed. Sediment of total saliva were extracted using phosphate buffer $0.2 \mathrm{M}$; pH 7.0 containing $0.1 \%$ CTAB [11].

A modified Lowry method by Hartree [12] was used to determine total serum, saliva and sediment proteins concentration using Bovine Serum Albumin (BSA) as a standard. Total Protein concentrations of serum, saliva and Pellet were expressed in $\mathrm{g} / \mathrm{L}$. Serum albumin was determined by dye-binding method [13] using kit manufactured by BioLabo. The concentration of globulin in serum samples of control and all patient groups was calculated, using the following equation: $\mathrm{C}_{\mathrm{glob}}(\mathrm{g} / \mathrm{L})=\mathrm{C}_{\mathrm{TP}}$ $-\mathrm{C}_{\mathrm{alb}}$

$\mathrm{C}_{\mathrm{glob}}=$ concentration of globulin

$\mathrm{C}_{\mathrm{TP}}=$ concentration of Total Protein

$\mathrm{C}_{\mathrm{alb}}=$ concentration of albumin

Throughout the present study conventional polyacrylamide gel (7.5\%) electrophoresis (PAGE) was 
carried out on sera and saliva samples of control and patients group to detect the differences in total proteins and glycoproteins present in the studied samples. Tris - glycine buffer $(0.075$ $\mathrm{M}, \mathrm{pH}$ 8.9) was used as the electrodes buffer solution. Prelectrophoresis conditions were $50 \mathrm{~mA}$ as a constant current for 30 minutes, with a voltage of $15 \mathrm{v} / \mathrm{cm}$, and at $4^{\circ} \mathrm{C}$. Electrophoresis was carried out for 10 minutes at $20 \mathrm{~mA}$, then the process was continued for 3.5 hours at $4^{\circ} \mathrm{C}$ by using $40 \mathrm{~mA}$ as a constant current and voltage of $15 \mathrm{v} / \mathrm{cm}$ (LKB note). The separation of different proteins is based on the differences in both molecular size and the charge of these proteins. The polyacrylamide gel was stained for protein, using silver stain [14], while Schiff's reagent was used for glycoprotein detection [15].

Statistical analysis was carried out using the program Statistical Package for the Social Science (SPSS for windows, version 16.0). The differences between groups were tested by the student t-test, and P-value was considered significant if it is $<0.05$. (SPSS version 16 software packages used).

\section{Results and discussion:}

Many researchers pointed out to the possibility of using saliva rather than blood as a diagnostic non-invasive body fluid [16, 17, and 18]. Several studies determined proteins concentration in the supernatant of saliva in patients with various diseases such as different types of cancer: breast cancer, ovarian cancer, oral cancer, and leukoplakia [19, 20, 21, and 22].

Therefore in the current study the changes in salivary proteins and sera proteins were followed using electrophoresis. These changes were examined in different samples: blood and whole saliva. The results are shown in Figure 1 where the electrozymogram shows distinct differences in salivary protein profile in the studied group.

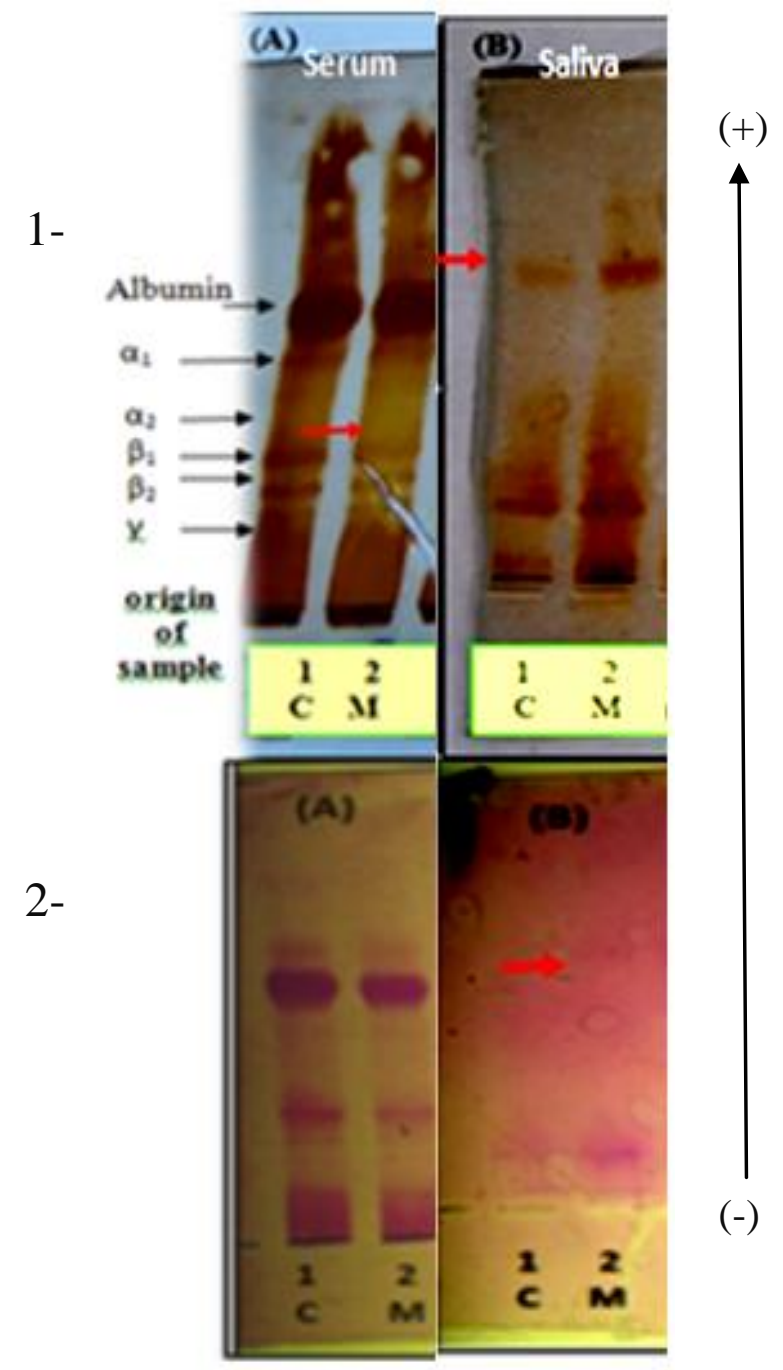

Fig 1: Electrozymogram showing protein and glycoprotein profile using $7.5 \%$ acrylamide gel.

Electrogram A 1\&2 refer to: 1 pooled crude sera (control) (C) \&2 pooled crude sera (malignant) (M) (OSCC). While electrogram B $1 \& 2$ refer to: 1 pooled crude saliva (control) (C) \& 2 pooled crude saliva (malignant) (M (OSCC). The red arrows refer to the extra bands appears in the indicated samples.

As it is clear there is a visible increase in the density in the region of the $\gamma$-globulins bands associated with 
an increase in albumin in saliva samples of patients with Oral Squamous Cell Carcinoma. As well as there is a slight increase in the region belongs to $\alpha_{2}$-globulins bands, in contrast a slight decrease in $\alpha_{1}$ globulins and $\beta$-globulin bands were observed. Moreover, there is a slight reduction in the intensity of bands that belong to $\gamma$ region. It is clearly obvious from the zymogram additional band (the red arrow) appeared in saliva samples of patients with oral squamous cell carcinoma in comparison to that of the control samples), and this band moved further toward the anode.
The differences are also clear among the studied group when the gel was stained for glycoproteins where the above mentioned additional band appeared to be glycoproteins. Also the change in glycoproteins profile is clear particularly in the globulins region. This may be related to the changes in cell surface glycoproteins during malignancy and as a result of synthesis of the acute phase proteins during inflammation processes [23].

To measure the observed change quantitatively the concentration of protein was measured in whole mixed saliva, supernatant and the pellet fraction. The results of measurements are illustrated in Table 2.

Table 2: Comparison of total protein in saliva samples of patients with Oral squamous cell carcinoma.

\begin{tabular}{|c|c|c|c|c|c|}
\hline Group & $\begin{array}{c}\text { Age (years) } \\
\text { Mean } \pm S D \\
(\text { Range })\end{array}$ & $\begin{array}{c}\text { Total protein } \\
(\mathrm{g} / \mathrm{L})\end{array}$ & Total saliva & $\begin{array}{c}\text { Supernatant of } \\
\text { Saliva } \\
\end{array}$ & $\begin{array}{c}\text { Pellet of } \\
\text { saliva }\end{array}$ \\
\hline $\begin{array}{c}\text { Control } \\
(\mathrm{n}=20)\end{array}$ & $\begin{array}{c}56.45 \pm 10.17 \\
(46-79)\end{array}$ & $\begin{array}{c}\text { Mean } \pm \text { SD } \\
\text { (Range) }\end{array}$ & $\begin{array}{c}2.69 \pm .961 \\
(1.58-4.71)\end{array}$ & $\begin{array}{c}2.136 \pm .737 \\
(1.28-3.4) \\
\end{array}$ & $\begin{array}{l}.223 \pm .101 \\
(.083-.51) \\
\end{array}$ \\
\hline \multirow{2}{*}{$\begin{array}{c}\text { Malignant } \\
\text { (OSCC) } \\
(n=18)\end{array}$} & \multirow{2}{*}{$\begin{array}{c}59.24 \pm 11.63 \\
(43-85)\end{array}$} & $\begin{array}{c}\text { Mean } \pm \text { SD } \\
\text { (Range) }\end{array}$ & $\begin{array}{c}4.37 \pm 1.34 * \\
(2.45-6.0)\end{array}$ & $\begin{array}{c}2.711 \pm .822 * \\
(1.5-4.1)\end{array}$ & $\begin{array}{c}.461 \pm .336 * \\
(.137-1)\end{array}$ \\
\hline & & P-value & .000 & .037 & .005 \\
\hline
\end{tabular}

* Significant difference in comparison to control at $(\mathrm{P}<0.05)$.

The results in this table reveal the presence of a significant increase ( $\mathrm{p}$ $<0.05)$ in whole, supernatant and pellet saliva proteins of patients with malignant tumors (OSCC) in comparison to that of the control, where an increase of $35.82 \%$ were observed in the patients group. Shpitzer et al reported that there was a $26 \%$ increase of total saliva protein in patients with oral squamous cell carcinoma in comparison with healthy controls. This increase is in agreement with other studies carried on (OSCC) patients whereas an increase in salivary total protein concentration in total saliva was also recorded in $[24,25,26$, 27, and 28] studies.
On measuring the percentage of total protein that is present in the saliva supernatant and saliva pellet in relation to the concentration protein in total saliva, it was found: - That in the patients group, $79.41 \%$ and $8.29 \%$ of total protein was measured in the supernatant and pellet of the saliva respectively. In the controls group, $62.04 \%$ and $10.55 \%$ of total saliva proteins was detected in the supernatant and pellet saliva samples respectively.

The saliva pellet's proteins is significantly higher in patients with OSCC than that of the control group (table 2), and this may be explained by the presence of dead cells in the saliva pellet of the patients. The proteins 
concentration of the saliva supernatant and pellet collectively is less than that of whole saliva, which may be due to denaturation of some of the proteins during preparation and separation.
Concentration of total protein, albumin and globulin were measured in sera sample and the results are presented in Table 3 .

Table 3: Comparison of total protein, Albumin, Globulins \& Albumin/Globulin Ratio in sera samples of patients with Oral squamous cell carcinoma.

\begin{tabular}{|c|c|c|c|c|c|}
\hline \multirow{2}{*}{ Group } & \multirow{2}{*}{$\begin{array}{c}\text { Age (years) } \\
\text { Mean } \pm \text { SD } \\
\text { (Range) }\end{array}$} & \multicolumn{4}{|c|}{$\begin{array}{c}\text { Mean } \pm \text { SD } \\
\text { (Range) }\end{array}$} \\
\cline { 3 - 6 } & & \multicolumn{4}{|c|}{ P-value } \\
\cline { 3 - 6 } & & $\begin{array}{c}\text { Total protein } \\
(\mathrm{g} / \mathrm{L})\end{array}$ & $\begin{array}{c}\text { Albumin } \\
(\mathrm{g} / \mathrm{L})\end{array}$ & $\begin{array}{c}\text { Globulin } \\
(\mathrm{g} / \mathrm{L})\end{array}$ & $\begin{array}{c}\mathrm{A} / \mathrm{G} \\
\text { Ratio }\end{array}$ \\
\hline \multirow{2}{*}{$\begin{array}{c}\text { Control } \\
(\mathrm{n}=20)\end{array}$} & $\begin{array}{c}56.45 \pm 10.17 \\
(46-79)\end{array}$ & $\begin{array}{c}75.09 \pm 5.35 \\
(62.33-84.37)\end{array}$ & $\begin{array}{c}44.01 \pm 2.78 \\
(40-48)\end{array}$ & $\begin{array}{c}31.32 \pm 4.95 \\
(20.33-38)\end{array}$ & $\begin{array}{c}1.44 \pm .25 \\
(1.13-2)\end{array}$ \\
\hline \multirow{2}{*}{$\begin{array}{c}\text { Malignant } \\
\text { (OSCC) } \\
(\mathrm{n}=18)\end{array}$} & $\begin{array}{c}59.24 \pm 11.63 \\
(43-85)\end{array}$ & $\begin{array}{c}74.05 \pm 8.53 \\
(60.19-86)\end{array}$ & $\begin{array}{c}38.05 \pm 3.87^{*} \\
(33-43)\end{array}$ & $\begin{array}{c}35.04 \pm 5.66^{*} \\
(25.43-45.5)\end{array}$ & $\begin{array}{c}1.04 \pm .19^{*} \\
(.77-1.45)\end{array}$ \\
\cline { 3 - 6 } & & .657 & .000 & .040 & .000 \\
\hline
\end{tabular}

* Significant difference in comparison to control at $(\mathrm{P}<0.05)$.

The results showed a decrease in total serum protein concentration in sera samples of patients with Oral Squamous Cell Carcinoma in comparison to that of the control samples in the study but the decrease was non-significant $(\mathrm{p}>0.05)$.

The results of the albumin concentration in sera samples of patients and control group are presented in Table 3. A significant decrease $(15.66 \%)$ in serum albumin was observed in patients' samples in comparison with that of the healthy control samples. Such result was confirmed by the electrozymogram Figures 1.

Albumin, which is produced in the liver, is a major plasma protein [29]; Since albumin is the major protein present in blood (a bout $60 \%$ of total serum protein ), so any condition causing lowering of serum albumin will lead to a reduced total serum protein (hypoproteinemia), but hypoproteinemia may be due to hypogammaglobulinemia as well [30, 31]. In malignant neoplasia there will be a catabolic state mediated by many cytokines, this catabolic state is necessary to supply the malignant cells with the primary materials necessary for cell division and growth as long as albumin acts as a source of nutrition to cells where it is hydrolysed to supply the raw materials [32]. In addition to this malignancy is known to be associated with high oxidative stress and as albumin may play a role as a sacrificial anti oxidant (it is destroyed by reactive oxygen species when it functions as an antioxidant), this may have an effect on the level of albumin in serum $[33,29,34]$.

Globulin concentration in sera samples of the studied group was calculated and the result (Table 3) indicated that there is a significant increase in globulin concentration in patients samples compared with that in healthy controls in the study (which observe in Figures 1). Globulins are another type of protein, larger in size than albumin. They are divided into three main groups: alpha, beta, and gamma [9]. The observed increase in S.globulins may be explained as follows: an increase in serum globulins may be a compensatory reaction to the decrease in serum albumin to maintain osmotic pressure of plasma [7]. 
Also different components of globulins increase as a result of synthesis of positive acute phase reactants. The impact of increase of S.globulins is less than the impact of decrease in S.albumin on T.S.P. so T.S.P decreases in significant hypo albuminemia despite the increase in serum globulins.

The ratio of serum albumin to globulin in patients and healthy controls of the study group was determined mathematically and the results were presented in Table 3. A significant decrease in this value was found in patients samples compared with healthy controls in the studied group. In our study a decrease in this value is due to decrease serum albumin and increase in serum globulins, but the decrease in serum albumin was greater so the net level of total serum protein was slightly decreased

The current study is a pilot one which pointed out to presence of an alteration in glycoproteins profile in sera \& saliva samples of the oral squamous cell carcinoma patients. Further studies are carrying out in our laboratory which concentrates on the additional band which was detected in saliva samples to find out the possibility of using this band to diagnose the disease. Since early detection of oral squamous carcinoma is the corner stone in effective management of these devastating tumors. This trial may represent a step in the efforts of early detection of this condition.

\section{Reference:}

1. Muwonge R, Ramadas K, Sankila R, Thara S, Thomas G, Vinoda J \& Sankaranarayanan R. 2008. Role of tobacco smoking, chewing and alcohol drinking in the risk of oral cancer in Trivandrum, India: A nested case- control design using incident cancer cases. Oral Oncology. 44: 446- 454.

2. Brinkman B \& Wong D. 2006.

Disease mechanism and biomarkers of oral squamous cell carcinoma. Curr Opin Oncol.18 (3): 228-233.

3. Giele H \& Cassell O. 2008. Plastic and reconstructive surgery. $1^{\text {st }}$ ed. Oxford University press Inc Publications, USA. P 344-356.

4. Results of Iraqi cancer registry. (2000, 2001, 2003, 2004): Ministry of Health, Iraq Cancer Registry Center Publications, Baghdad, Iraq.

5. Burtis CA, Ashwood ER \& Bruns DE. 2008. Fundamentals of Clinical Chemistry. $6^{\text {th }}$ ed. Elsevier Inc Publications, New Delhi. P: 286-316.

6. Murray RK, Granner DK \& Rodwell VW. 2006. Harper's Illustrated Biochemistry.27 $7^{\text {th }}$ ed. McGraw-Hill Publications, U.S.A. p: 588-605.

7. Chatterjea MN \& Shinde R. 2007. Textbook of Medical Biochemistry. $7^{\text {th }}$ ed. Jaypee Brothers Medical Publications, New Delhi. P 92-113.

8. Vasudevan DM \& Sreekumari S. 2007. Textbook of Biochemistry. Jaypee Brothers Medical Publications, New Delhi. p: 237-250

9. Marshall WJ \& Bangert SK. 2008. Clinical Chemistry. $6^{\text {th }}$ ed. Elsevier Limited Publications, UK.p.253-270.

10. Farnaud JCS, Kosti O, Getting SJ \& Renshaw D. 2010. Saliva: Physiology and Diagnostic Potential in Health and Disease Review. The Scientific World J. 10: 434-456.

11. Thomas EL, Jefferson MM, Joyner RE, Cook GS \& King CC. 1994. Leukocyte myeloperoxidase and salivary lactoperoxidase: identification and quantitation in human mixed saliva. J Dent Res.73(2): 544-555.

12. Hartree EF. 1972. Determination of protein: a modification of the Lowry method that gives a linear photometric response. Anal Biochem. 48: 422-427. 
13. Doumas BT, Watson WA, \& Biggs HG. 1971. Albumin standards and the measurement of serum albumin with bromocresol green. Clin Chim Acta. 31: 87-96.

14. Celis JE, Carter N, Hunter T, Simons K, Small JV \& Shotton D. 2006. Protein Detection in Gels by Silver Staining: A Procedure Compatible with Mass-Spectrometry. Cell Biology: A Laboratory Handbook. $3^{\text {rd }}$ ed. Elsevier. Academic Press Publications, USA.p 1-8.

15. Leach BS, Collawn FJ \& Fish WW. 1980. Behavior of glycopolypeptides with empirical molecular weight estimation methods. Biochemistry. 19: 5734-5741.

16.

Hu S, Xie Y \& Ramachandran P. 2005. Large-scale identification of proteins in human salivary proteome by liquid chromatography/ mass spectrometry and two-dimentional gel electrophoresis-mass spectrometry. Proteomics. 5: 1714-1728.

17. Kingsmore SF. 2006. Multiplexed protein measurement: technologies and applications of protein and antibody arrays. Nat Rev Drug Discov. 5: 310-321.

18. Arellano-Garcia ME, $\mathrm{Hu} \mathrm{S}$, Wang J, HensonB, Zhou H, Chia D \&Wong DT. 2008. Multiplexed immunobead-based assay for detection of oral cancer protein biomarkers in saliva. Oral Diseases. 14( 8): 705-712. 19. Streckfus D, Bigler L, Tucci M \& Thigpen JT. 2000. A preliminary study of CA15-3, c-erbB-2, epidermal growth factor receptor, cathepsin-D, and p53 in saliva among women with breast carcinoma. Cancer Invest 18: 101-109.

20. Gorelik E, Landsittel DP \& Marrangoni AM 2005. Multiplexed immunobead-based cytokine profiling for early detection of ovarian cancer. Cancer Epidemiol Biomarkers Prev. 14: 981-987.
21. Rhodus NL, Ho V, Miller CS, Myers S \& Ondrey F. 2005. NFkappa $\mathrm{B}$ dependent cytokine levels in saliva of patients with oral preneoplastic lesions and oral squamous cell carcinoma. Cancer Detect Prev. 29: 42-45.

22. Brailo V, Vucicevic-Boras V, Cekic-Arambasin A, Alajbeg IZ, Milenovic A \& Lukac J. 2006. The significance of salivary interleukin 6 and tumor necrosis factor alpha in patients with oral leukoplakia. Oral Oncol. 42: 370-373.

23. ceciliani fabrizio, pocacqua Vanessa.2007. The acute phase protein $\alpha 1$-Acid glycoprotein: a model for altered glycosylation during diseases.Current protein and peptide science. 8(1): 91-108(18).

24. Al-Rawi NH. 2001. Measurement of trace elements, enzymes, proteins in saliva, serum and tissue extracts in patients with oral cancer. Baghdad University, College of Dentistry. Thesis.

25. Ibrahim H M. 2003. Salivary and plasma markers as a diagnostic tool for ion transport alteration and oxidative stress: an association with different histological grades in oral sequamous cell carcinoma patients. Baghdad University, College of Dentistry. Thesis.

26. Shpitzer T, Bahar G, Feinmesser R \& Nagler RM. 2007. A comprehensive salivary analysis for oral cancer diagnosis. J Cancer Res Clin Oncol. 133: 613-617.

27. Daoud R M. 2008. Study of Some Biochemical Changes in Serum \& Saliva of Patients with Oral Epithelial Tumors. Baghdad University, College of Science, Chemistry Department. Thesis.

28. Sanjay PR, Hallikeri K \& Shivashankara AR. 2008. Evaluation of salivary sialic acid, total protein, and total sugar in oral cancer: A 
preliminary report. Indian J Dent Res. 19(4): 288-291.

29. Mallikarjunappa S \& Prakash M. 2007. Urine protein thiols in chronic renal failure patients. Indian $\mathbf{J}$ Nephrology. 17(1): 7-9.

30. Murray RK, Granner DK \& Rodwell VW. 2006. Harper's Illustrated Biochemistry. $27^{\text {th }}$ ed. McGraw-Hill Publications, U.S.A. p: 588-605.

31. Vasudevan DM \& Sreekumari S. 2007. Textbook of Biochemistry. Jaypee Brothers Medical Publications, New Delhi. p: 237-250.
32. Burtis CA, Ashwood ER \& Bruns DE. 2008. Fundamentals of Clinical Chemistry. $6^{\text {th }}$ ed. Elsevier Inc Publications, New Delhi. p: 286-316.

33. Olinescu R \& Terrance IS. 2002. Free Radicals in Medicine. Nova Science Publications, U.S.A. p: 87119.

34. Karthikeyan K, Sinha I, Prabhu K, Bhaskaranand N \& Rao A.2008. Plasma Protein Thiols and Total Antioxidant Power in Pediatric Nephrotic Syndrome. Nephron Clin Pract.110 (1): 110-114.

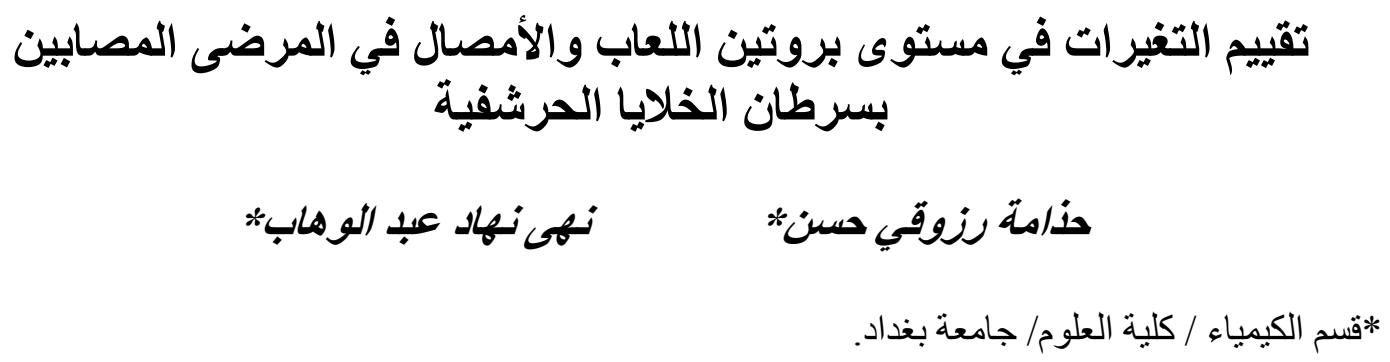

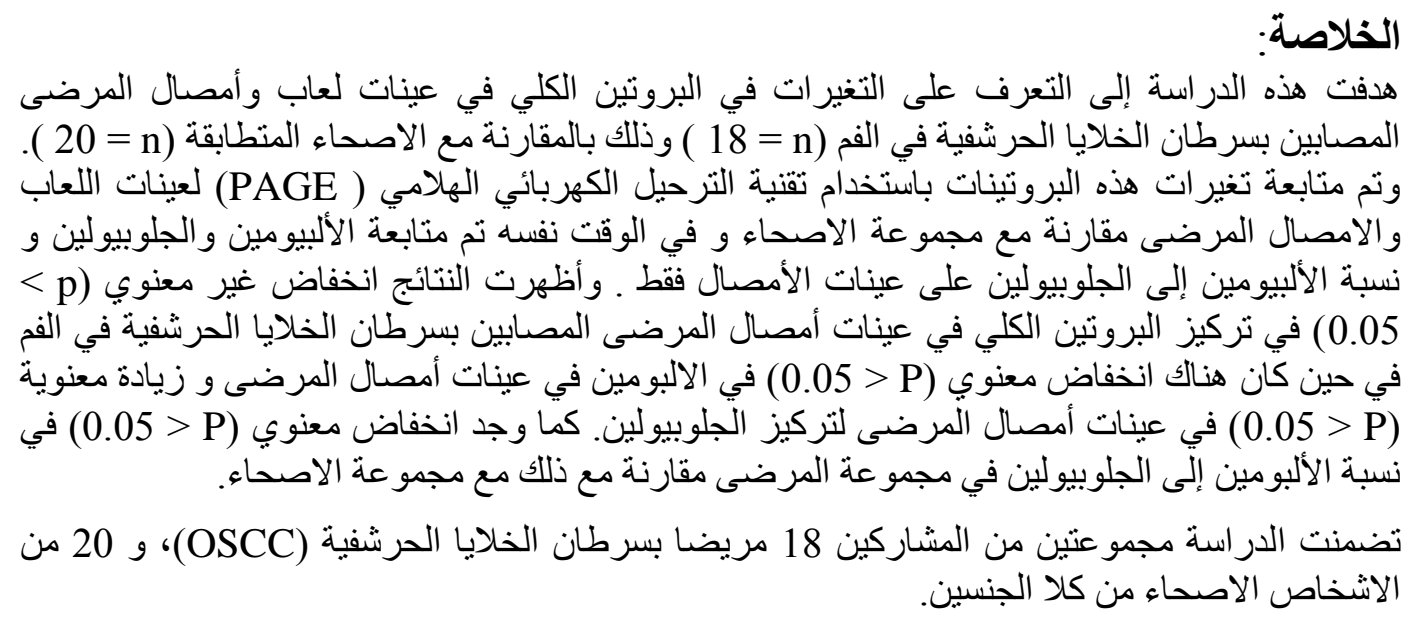

